\title{
The Comparison of The Unit Cost Of Hemodialysis With Ina Cbg Rates In Muhammadiyah Siti Aminah Hospital
}

\author{
Gigin Bian Rosmila \\ RSU Muhammadiyah Siti Aminah Bumiayu, Jawa Tengah, Indonesia \\ Rizal Yaya \\ Universitas Muhammadiyah Yogyakarta, Yogyakarta, Indonesia \\ Firman Pribadi \\ Universitas Muhammadiyah Yogyakarta, Yogyakarta, Indonesia
}

\begin{abstract}
Health services in Indonesia have led to the National Health Insurance. Hospitals that serve BPJS participants are paid using a package system based on INA CBG rates. Payment of claims to advanced health facilities is differentiated by type of hospital. Type $D$ hospitals have the lowest INA CBG rates, so they must calculate the unit cost of each procedure given based on the diagnostic group. The purpose of this study was to determine the comparison of the unit cost of hemodialysis measures with INA CBG rates and to find out if there are non-value-added activities in services. This type of research was a qualitative case study. The subject of the study was Muhammadiyah Siti Aminah General Hospital. The object used was all activities that support the occurrence of hemodialysis outpatient services. Data analysis used Activity Based Costing Baker modification. The results shows a unit cost of HD action in 2018 of Rp. 724.725. INA CBG rate for hemodialysis action in Type D Hospital is Rp. 737.700,--. So that a positive difference is obtained between the INA CBG rate and the HD unit cost of Rp. 12,975 -. RSUMSA has not been able to conduct supporting examinations in accordance with the specified standards because the costs incurred will be very high and will cause losses because they exceed INA CBGS tariffs and no potential non-value added activities are found.
\end{abstract}

Keywords: Unit Cost; Hemodialisis; Tarif INA CBG

\section{INTRODUCTION}

Chronic Kidney Disease (CKD) is a global health problem that is difficult to be controlled. This is proven by the Global Burden of Disease data of 2010 which shows that in 2010, CKD was the 18th leading cause of death in the world. In the world, CKD sufferers who get dialysis or kidney transplant treatments reach more than 2 million people but only $10 \%$ actually undergo these treatments. Basic Health Research Data (Riskesdas) in 2013, showed the prevalence of kidney failure patients in Indonesia is 2 per 1000 population or equal to $0.2 \%(1)$. 
The number of new patients and active patients continues to increase. In 2007, there were 4,977 new patients and only 1,885 active patients. Whereas as of December 31, 2017, new patient data has reached 30,831 and active patients have reached 77,892.(2) The increasing number of hemodialysis patients drives health facilities to open hemodialysis services. In 2015 there were 382 renal units in Indonesia, the number continued to increase until in 2017 of 710 HD units. Of the 710 units, $57 \%$ of these were organized by the private sector, $39 \%$ by the government, $3 \%$ by the TNI and Polri Hospital and 1\% by individual clinics.(2)

For funding facilities, in 2015 there was a drastic change where the 86\% financing guarantee was from the National Health Insurance (JKN). There are $71 \%$ of JKN PBI patients (recipient of contribution assistance) while $15 \%$ are JKN Non PBI. (3) The percentage of hemodialysis financing by JKN continues to increase, in 2017 it reached 89\%. (2). From the above data, hospitals must really conduct a cost analysis for hemodialysis, because most of the funding comes from the JKN program.

Based on the data above, CKD is the second biggest catastrophic disease in Indonesia that spends health costs after heart disease. Data Center for Health Financing and Health Insurance of the Ministry of Health in 2016, the catastrophic diseases cost 8.2 trillion in 2014, and increased to 13.1 trillion in 2015 and 13.3 trillion in 2016. Therefore in 26 October 2016 Ministry of Health issued Minister of Health Regulation No. 52 of 2016 concerning Health Service Tariff Standards in Implementing Health Insurance Programs in lieu of Minister of Health Regulation No. 59 of 2014 concerning Health Service Tariff Standards in the Implementation of the Health Insurance Program where the hemodialysis service rates for patients with chronic kidney failure are reduced. The lowered hemodialysis rates are expected to reduce the burden of health costs that must be paid by BPJS Health. However, this makes the hospital management that organizes hemodialysis services must recalculate whether this hemodialysis service is still beneficial for the hospital. For type D hospitals, the calculation of unit cost is a necessity that must be done because the INA CBG rates in the type D hospital are the lowest, namely Rp. 737,700. (4)

Health services in Indonesia are now heading towards universal health coverage. The President of the Republic of Indonesia established an organizing body namely the Health Insurance Administering Board (BPJS). Hospitals that serve BPJS participants are paid using a package system based on INA CBG (Indonesian Casemix Based Groups) rates. The INA CBG tariff includes all costs incurred by the health services that have been provided to patients such as doctor's examination fees, medication, accommodation, supporting examinations, use of medical devices and all medical measures during treatment. This payment is based on the diagnosis group, procedure and type of hospital. For type D hospitals, they have the lowest INA CBG rates. So the hospital must calculate the unit cost of each action or procedure given to patients based on the diagnosis group.(5)

Muhammadiyah Siti Aminah Hospital (RSUMSA) is a Muhammadiyah Persyarikatan Hospital managed by the Branch Manager of Muhammadiyah Bumiayu. In 2016, RSUMSA continued to develop and improve the quality of services as evidenced by the achievement of the Prime Accreditation in May 2016. Specialist physician services are also experiencing growth, plus the services of Skin, Eyes and Anesthetics. The number of beds has also increased to 81 beds. In addition, RSUMSA also conducted a feasibility study for the addition of hemodialysis services. Planning for additional RSUMSA hemodialysis services was carried out at the end of 2016. One 
Rosmila, G. B., Yaya, R., \& Probadi, F. (2020) The Comparison Of The Unit Cost Of Hemodialysis With Ina Cbg Rates In Muhammadiyah Siti Aminah Hospital. Archives of Business Research, 8(5). 80-95.

consideration will be opening up hemodialysis services because there are no hospitals that have hemodialysis facilities in the Southern District of Brebes.

From a financial perspective, hemodialysis was considered profitable at the time because it used JKN rates based on PMK No. 59 of 2014 concerning the National Health Insurance Tariff Standard of Rp. 812,100, - for Type D Hospital in Regional I. However, when RSUMSA has prepared hemodialysis services, the Government of the Republic of Indonesia has decided to lower the standard hemodialysis rates by applying PMK No. 52 of 2016 concerning Health Services Standard Tariffs in the Implementation of the Health Insurance Program to Rp. 737,700, for Private Type D Hospitals in Regional I. Although the hemodialysis service rates from the JKN program have decreased, RSUMSA remains committed to providing hemodialysis services for the people of Southern Brebes Regency. Finally, the Hemodialysis Installation at RSUMSA began to be opened in March 2018.

Since the opening of the hemodialysis service, RSUMSA management has not finalized a detailed calculation of how much the unit cost of hemodialysis is. New hospital management calculates the costs incurred for the purchase of hemodialysis fluids, medicines used, consumables and costs for doctor's services. Hospital management has not yet included the overhead spent on Hemodialysis Installation. RSUMSA Hemodialysis Installation Revenue is currently $100 \%$ derived from BPJS Health claims with INA CBG rates per hemodialysis action of Rp. 737,700. Therefore it is important to conduct research on hemodialysis unit costs in RSUMSA so that hospital management knows what the actual unit cost of hemodialysis is and whether this service is still beneficial for hospitals with class D types such as Muhammadiyah Siti Aminah General Hospital.

Activity based costing (ABC) is one type of methodology for calculating cost (cost accounting). (6) This method is considered the best of various other cost analysis methods in health services. (7) $A B C$ is different from traditional methodology, where $A B C$ fundamentally concentrated on activities that incur costs. Principles of $\mathrm{ABC}$ is to produce a product, the activity of consuming resourches. So $\mathrm{ABC}$ can interpreted as a methodology for calculating the costs and performance of activities, resourches and cost objects. Resourches are assigned to activities, activities are assigned to cost objects based on their use. $\mathrm{ABC}$ introduces the relationship between cost drivers and activities (6).

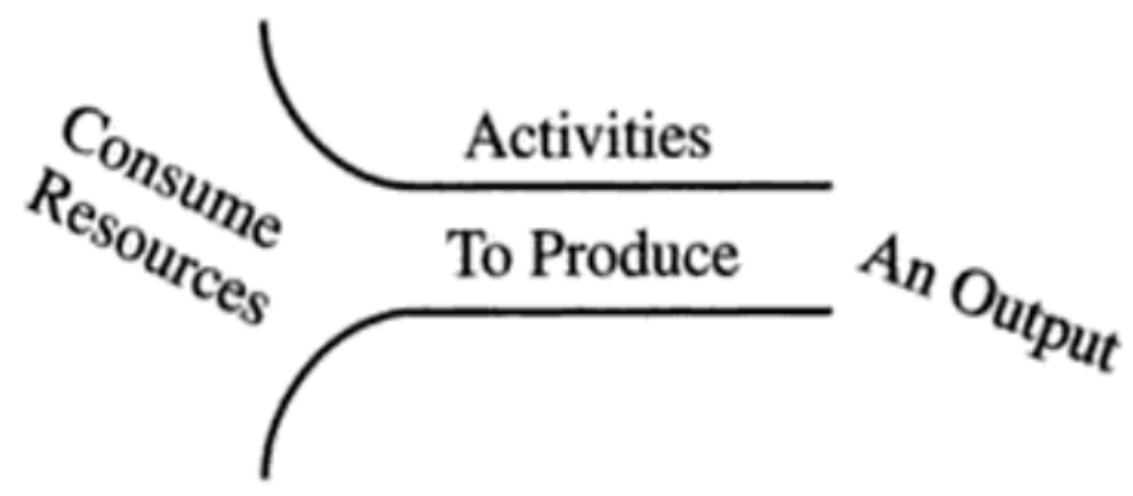

Figure 1. Theory of Resourches Consumption

Source: Baker, 1998 


\section{METHODS}

This study was a qualitative research by using case study method. This study aimed to determine the unit cost of hemodialysis services in hospitals. The subject of the research was Muhammadiyah Siti Aminah General Hospital (RSUMSA) Brebes, Central Java. The objects used were all activities in RSUMSA that support the occurrence of outpatient hemodialysis (HD) services at the Hemodialysis Installation. The research instruments used were interviews, documents and observations. Data analysis used the ABC (Activity Based Costing) -Baker modification method.(610)

\section{Profile of Hemodialysis Service at RSUMSA}

\section{RESEARCH RESULT}

Hemodialysis services at RSUMSA began in March 2018. Hemodialysis machine procurement in collaboration with third parties. The hospital is obligated to purchase consumables from the company. At the beginning of March, HD RSUMSA installation operated using 4 machines, until the end of 2018 there were already 6 machines. With 2 services, the number of patient that can be served by HD RSUMSA Installation is 36 patients. The number of HD actions during 2018 is 2416.

\section{Characteristics of Subject}

The interview were conducted with hospital staff such as hospital director, doctors, nurse of HD installation, financial staff, infrastructure staff and other staff involved in HD services. In addition, observation were made on patients undergo hemodialysis. Observation were made on 30 patients. The age of the pastient is $66,7 \%$ in the age range of $40-60$ years (Table 1 ).

Table 1. Characteristics of Observed Respondents $(n=30)$

\begin{tabular}{|c|c|}
\hline Characyeristics & $\mathbf{n}(\%)$ \\
\hline \multicolumn{2}{|c|}{ Age (years old) } \\
\hline$<40$ years old & $10(33.3)$ \\
\hline $40-60$ years old & $16(53.3)$ \\
\hline$>60$ years old & $4(13.3)$ \\
\hline \multicolumn{2}{|c|}{ Sex } \\
\hline Male & $18(60)$ \\
\hline Female & $12(40)$ \\
\hline Mnarital Status \\
\hline Mnmarried & $2(6.7)$ \\
\hline Married & $28(93.3)$ \\
\hline
\end{tabular}

\section{Activity Center Hemodialisis RSUMSA}

After identifying the flow of services, observations in the field and interviews with relevant staff, it can be concluded that the HD service activities in RSUMSA consist of 18 activity center. And all activities take 317 minutes. (Table 2) 
Rosmila, G. B., Yaya, R., \& Probadi, F. (2020) The Comparison Of The Unit Cost Of Hemodialysis With Ina Cbg Rates In Muhammadiyah Siti Aminah Hospital. Archives of Business Research, 8(5). 80-95.

\section{Table 2. RSUMSA Hemodialysis Installation Activity Center}

\begin{tabular}{|c|l|c|}
\hline No. & \multicolumn{1}{|c|}{ Type of Activities } & Times (Minute) \\
\hline 1 & Patient Registration & 3 \\
\hline 2 & Weighing & 1 \\
\hline 3 & Anamneses dan TTV Examination & 5 \\
\hline 4 & Machine Preparation & 5 \\
\hline 5 & Installing Blood Line, Dialyzer, Nacl & 3 \\
\hline 6 & Soaking & 2 \\
\hline 7 & Priming & 10 \\
\hline 8 & Vascular Access Function & 5 \\
\hline 9 & Linking Venus Fistula Artery with Blood Line & 2 \\
\hline 10 & Setting the machine according to dosage & 1 \\
\hline 11 & Observation & 240 \\
\hline 12 & Doctor Visiting & 6 \\
\hline 13 & Hemodialysis Finalization & 5 \\
\hline 14 & Final Weighing & 1 \\
\hline 15 & Changing linen & 10 \\
\hline 16 & Rinsing & 2 \\
\hline 17 & Preparing Patients Status & $\mathbf{3 1 7}$ \\
\hline 18 & Reuse & \\
\hline & & Total of time \\
\hline
\end{tabular}

\section{Supporting Examination of Hemodialysis Patients Conducted at RSUMSA}

Regular laboratory examinations are performed on all HD patients both monthly, 3 months and every 6 months. The following are routine laboratory tests on HD patients:

Table 3. Types of Routine Laboratory Examinations in HD Patients

\begin{tabular}{|l|l|}
\hline \multicolumn{1}{|c|}{ Schedule of Routine Examination } & \multicolumn{1}{|c|}{ Type Laboratory Examination } \\
\hline Once a month & $\mathrm{Hb}$ \\
\hline Once every 3 months & Ureum, creatinine \\
\hline Every 6 months & $\mathrm{HCV}, \mathrm{HIV}, \mathrm{HbsAg}$ \\
\hline
\end{tabular}

Based on the above types of examinations, a routine examination fee that must be incurred for each HD patient was Rp. 258,782, 00, with details as listed in the table below.

Table 4. Cost of Routine Supporting RSUMSA HD Patients

\begin{tabular}{|c|c|c|}
\hline Type of Examintations & Cost Driver & Unit Cost (Rp) \\
\hline $\mathrm{Hb}$ & Test & 57.449 \\
\hline Ureum & Test & 50.882 \\
\hline Creatinine & Test & 90.463 \\
\hline HCV & Test & 26.944 \\
\hline HIV & Test & 6.100 \\
\hline HbsAg Test & 26.944 \\
\hline \multicolumn{2}{|c|}{ Total } \\
\hline
\end{tabular}


If the supporting examination for HD patients is carried out in accordance with Pernefri's recommendation, the cost must be Rp. 4,020,101.00. This cost was very high because many laboratory examinations must be sent to third parties (outside laboratories that have collaborated with RSUMSA) because they are not available at RSUMSA Laboratories.

Tabel 5. The Cost of Supporting Examinations in Accorcande with the Recommendations of Pernefri

\begin{tabular}{|c|l|c|}
\hline No & \multicolumn{1}{|c|}{ Parameter } & Unit Cost \\
\hline 1. & Hemoglobin & 57.449 \\
\hline 2. & Trombosit & 57.449 \\
\hline 3. & Ferritin, Fe serum & 305.000 \\
\hline 4. & transferrin saturation & 415.000 \\
\hline 5. & Ureum & 50.882 \\
\hline 6. & Creatinin & 90.463 \\
\hline 7. & Lipid profile (cholesterol, TG, LDL and HDL) & 216.968 \\
\hline 8. & Uric acid & 50.882 \\
\hline 9. & Blood sugar & 50.882 \\
\hline 10. & Bicarbonate & 171.000 \\
\hline 11. & Potassium and Sodium & 162.436 \\
\hline 12. & Albumin & 23.938 \\
\hline 13. & Liver function (SGOT/ALT,SGPT/AST) & 101.764 \\
\hline 14. & HbsAg & 26.944 \\
\hline 15. & AntiHCV & 26.944 \\
\hline 16. & Anti HIV & 6.100 \\
\hline 17. & CRP & 307.000 \\
\hline 18. & Calsium, phosphate & 255.000 \\
\hline 19. & Parathyroid hormone (PTH) & 769.000 \\
\hline 20. & Beta2 microglobulin & 875.000 \\
\hline & & $\mathbf{4 . 0 2 0 . 1 0 1}$ \\
\hline & & \\
\hline
\end{tabular}

\section{Unit Cost Hemodialysis}

\section{Direct Costs for Hemodialysis}

Direct costs on HD measures consist of the costs of doctor's visiting services, nursing actions, costs of consumable medical materials and supporting examinations. Doctors visiting at the RSUMSA Hemodialysis Installation are carried out by Internal Medicine Specialists who have been certified HD training or general practitioners who have been certified HD training or general practitioners guarding wards. Following are the direct costs on HD actions at RSUMSA. 
Rosmila, G. B., Yaya, R., \& Probadi, F. (2020) The Comparison Of The Unit Cost Of Hemodialysis With Ina Cbg Rates In Muhammadiyah Siti Aminah Hospital. Archives of Business Research, 8(5). 80-95.

Table 6. HD Direct Costs

\begin{tabular}{|c|c|c|c|c|}
\hline Category of costs & Unit & Total & Unit cost & Total cost \\
\hline Registration & Action & 2416 & $15.000,00$ & 36.240 .000 \\
\hline $\begin{array}{l}\text { Visiting Doctor service Jasa } \\
\text { Visite Dokter }\end{array}$ & Action & 2416 & $45.000,00$ & 108.720 .000 \\
\hline Dialyzer & Unit & 480 & $153.300,04$ & 73.584 .019 \\
\hline Bloodline & Unit & 2974 & $65.300,40$ & 194.203 .390 \\
\hline AV fistula & Unit & 5776 & $7.300,00$ & 42.164 .800 \\
\hline Concentrate Part A & Bag & 1180 & $113.300,00$ & 133.694 .000 \\
\hline Concentrate Part B & Bag & 1130 & $113.300,00$ & 128.029 .000 \\
\hline Procide Disinfectant & Galon (5lt) & 24 & $2.200 .000,00$ & 52.800 .000 \\
\hline Inviclot Inj & Vial & 1415 & $69.300,00$ & 98.059 .500 \\
\hline Eporon $2000 \mathrm{IU} / 0.5 \mathrm{ml}$ & Box & 48 & $734.800,00$ & 35.270 .400 \\
\hline Eporon $3000 \mathrm{IU} / 0.3 \mathrm{ml}$ & Box & 1 & $990.000,00$ & 990.000 \\
\hline Hemapo Inj $3000 \mathrm{IU} / \mathrm{ml}$ & Amp & 60 & $108.900,00$ & 6.534 .000 \\
\hline Hemapo Inj $1 \mathrm{ml}$ & Vial & 15 & $77.000,00$ & 1.155 .000 \\
\hline Kassa sheet & Sheet & 4832 & 310,00 & 1.497 .920 \\
\hline Kassa Depper & Sheet & 4832 & 310,00 & 1.497 .920 \\
\hline Alkohol Swab 70 \% & Sachet & 9664 & 100,00 & 966.400 \\
\hline Hypafix $10 \times 5 \mathrm{~cm}$ bandage & Sheet & 2416 & $2.718,00$ & 6.566 .688 \\
\hline Handscoon & Pairs & 4832 & 640,00 & 3.092 .480 \\
\hline Masks & Sheet & 2416 & 320,00 & 773.120 \\
\hline Nacl $0.9 \% 1000 \mathrm{cc}$ & Flabot & 2416 & $7.164,00$ & 17.308 .224 \\
\hline Spuit $1 \mathrm{cc}$ & Unit & 2416 & 927,00 & 2.239 .632 \\
\hline Spuit $10 \mathrm{cc}$ & Unit & 2416 & $1.188,00$ & 2.870 .208 \\
\hline Spuit $20 \mathrm{cc}$ & Unit & 2416 & $1.954,00$ & 4.720 .864 \\
\hline Set HD Pack & Pack & 2416 & $22.900,00$ & 55.326 .400 \\
\hline Aseptic gell (Hand Rub) & Bottle & 48 & $18.865,00$ & 905.520 \\
\hline Pehidrol (H2O2 1\%) & $200 \mathrm{ml}$ & 2416 & 300,00 & 724.800 \\
\hline Renalin 3\% (10 lt) & $200 \mathrm{ml}$ & 2416 & $2.200,00$ & 5.315 .200 \\
\hline $\mathrm{Hb}$ & Test & 269 & $57.449,00$ & 15.453 .781 \\
\hline Ureum & Test & 48 & $50.882,00$ & 2.442 .336 \\
\hline Creatinine & Test & 49 & $90.463,00$ & 4.432 .687 \\
\hline Anti HCV & Test & 25 & $26.944,00$ & 673.600 \\
\hline Anti HIV & Test & 26 & $6.100,00$ & 158.600 \\
\hline HbsAg & Test & 25 & $26.944,00$ & 673.600 \\
\hline Examination Of Clean Water & Test & 1 & 1.500 .000 & 1.500 .000 \\
\hline Waste B3 & $\mathrm{Kg}$ & 4.832 & 25.000 & 120.800 .000 \\
\hline Total Direct Cost & & & & 1.161.384.089 \\
\hline Average per action & & & 480.705 & \\
\hline
\end{tabular}

Based on the table above, the total direct cost of HD service meaures was Rp. 1,161,384,089.00. Total hemodialysis action in 2018 were 2416 action, so the average direct cost per actions was Rp. 480,705.00. 


\section{Direct Resource Overhead Costs}

Direct resources overhead costs are overhead costs that are directly related to HD patients, namely employee salaries, maintenance costs for buildings and equipment, office costs, electricity costs, water costs, telephone costs, and cleaning costs in HD installations. The overhead direct resource costs can be categorized into 4 categories, namely:

1. Labor Related: The HD installation in RSUMSA has 4 workers, all of them nurses. Of these 4 people, 3 were HD certified training. The labor costs referred here are employee salaries, employee service incentives, meal allowances, BPJS Health benefits, BPJS Employment benefits, overtime pay and also the HD Installation employee training costs. Obtained HD installation labor costs in 2018 was Rp. 128,672,819.00.

2. Equipment Related: For related equipment, the cost calculated is the cost of maintaining medical and non-medical devices. HD machines used in RSUMSA are provided through the KSO system so that maintenance does not go into hospital costs. As the HD Installation at RSUMSA was only operational at the beginning of 2018, there has never been any maintenance of medical or non-medical equipment since all equipment is still new. In this category of costs only calculated depreciation of medical and non-medical devices for 11 months, amounting to Rp. 19,327,438.00.

3. Space Related: Space related in the HD installation of RSUMSA there are only depreciation costs of buildings. This is because the new HD Installation Building was built in 2017 and was only operational in 2018 and has never been maintained. So, that the cost of depreciation of buildings for 9 months was Rp. 7,232,006.00.

4. Service Related: Services related to HD Installation consist of office fees, service subscription fees (telephone, electricity and water), marketing costs and cleaning costs. In 2018 a service related fee was obtained for Rp. 135,172,994.00.

The total cost of direct installation overhead of HD Installation in 2018 was Rp. 290,405,257.00. This fee will be charged to all HD patients in 2018 based on the number of HD actions in 2018. So that every action is charged an overhead direct resource cost of Rp. 120,201.00

\section{Indirect resource overhead costs}

Cost of indirect resources overhead is overhead cost incurred by non-functional units, the cost of which will be charged to the HD Installation according to the proportion of loading. The proportion of loading is taken from the proportion of HD Installation income to total hospital income. Indirect overhead resources can be categorized into 4 categories, namely:

1. Labor Related: Data taken from the SDI (Human Resources) section and interviews of the General Manager and SDI, obtained data on the number of RSUMSA employees in 2018 were 282 employees. For non-functional units, there are 131 employees. Labor related costs include employee salaries, food allowances, health, labor insurance, service incentives, overtime pay and also training costs incurred by the finance department for employees in non-functional units. It is obtained indirect labor overhead resource related costs in 2018 of Rp. 4,925,156,098.00

2. Equipment Related: The equipment related consists of maintenance costs and depreciation costs for office equipment and furniture and vehicles that will be charged to the HD Installation. In 2018 non-functional equipment related unit costs were Rp. $723,182,887.00$ 
Rosmila, G. B., Yaya, R., \& Probadi, F. (2020) The Comparison Of The Unit Cost Of Hemodialysis With Ina Cbg Rates In Muhammadiyah Siti Aminah Hospital. Archives of Business Research, 8(5). 80-95.

3. Space Related: Space related in non-functional units consists of maintenance costs and depreciation of non-functional unit buildings. It is obtained non-functional space related unit costs in 2018 of Rp. 124,344,459.00

4. Service Related: Non-functional related service units consist of office costs, service subscription fees (telephone, electricity and water), marketing costs and cleaning service costs used in non-functional units. In 2018 a service related fee was obtained for Rp. $1,853,355,102.00$. The total cost of the non-functional unit overhead resource overhead was Rp. 7,626,038,546.00. This fee would be charged to the Hemodialysis Installation based on the proportion of HD Installation revenue to total hospital revenue in 2018.

\section{Proportion of Revenue}

The following table explains the breakdown of the hospital revenue in 2018. Hospital revenue for 1 year was taken from the income of each functional unit in RSUMSA. Total Hospital Revenue in 2018 was Rp. 50,819,740,031.00. HD income was Rp. 1,993,510,131. So that the proportion of HD income obtained was 3.9\%. Next will be calculated the imposition of indirect resource overhead costs for HD Installation using the proportion of HD Installation revenue.

Table 7. Basic Charges for Overhead Indirect Resource Costs

\begin{tabular}{|c|c|}
\hline Hospital revenue & 50.819 .740 .031 \\
\hline HD revenue & 1.993 .510 .131 \\
\hline Proportion & $3,9 \%$ \\
\hline Total Indirect Resource Overhead & 7.626 .038 .546 \\
\hline Indirect Resource Overhead HD(a) & 299.147 .243 \\
\hline Indirect Resource Overhead HD per Action(b) & 123.819 \\
\hline \multicolumn{2}{|c|}{$\begin{array}{l}\text { Explanation: } \\
\text { a) Indirect Resouce Overhead HD Cost = Total Indirect Resource Overhead x proportion } \\
(3,9 \%)\end{array}$} \\
\hline \multicolumn{2}{|c|}{ b) Indirect Resource Overhead HD Cost per action } \\
\hline
\end{tabular}

Based on the table above the cost of the inderect resources overhead cost based on the assumption that the proportion of the revenue is Rp. 123,819.00.

\section{Charging Overhead Costs into Activity Center HD}

The total HD overhead costs are obtained by adding direct HD overhead resources with indirect HD overhead resources. 
Table 8. Total Overhead HD Costs

\begin{tabular}{|c|c|c|c|c|}
\hline No & Overhead Cost & Cost Driver & DIRECT (Rp) & INDIRECT (Rp) \\
\hline \multicolumn{5}{|c|}{ Labour Related } \\
\hline 1 & Labor cost & Numer of labor & 65.672 .819 & 158.568 .536 \\
\hline \multirow[t]{2}{*}{2} & Training cost & Number of labor & 63.000 .000 & 34.142 .781 \\
\hline & Sub Total & & 128.672 .819 & 192.711 .317 \\
\hline \multicolumn{5}{|c|}{ Equipment Related } \\
\hline 1 & $\begin{array}{l}\text { Maintenance of Medic and Non- } \\
\text { Medic Equipments } \\
\end{array}$ & Number of visits & - & 4.825 .206 \\
\hline \multirow[t]{2}{*}{2} & $\begin{array}{l}\text { Depreciation of medic and non- } \\
\text { medic equipments }\end{array}$ & Work hours & 19.327 .438 & 23.471 .466 \\
\hline & Sub Total & & 19.327.438 & 28.296 .672 \\
\hline \multicolumn{5}{|c|}{ Space Related } \\
\hline 1 & Mainntenance od buildings & Work hours & - & 788.833 \\
\hline \multirow[t]{2}{*}{2} & Depreciation of buildings & Work hours & 7.232 .006 & 4.076 .512 \\
\hline & Sub Total & & 7.232 .006 & 4.865 .345 \\
\hline \multicolumn{5}{|c|}{ Service Related } \\
\hline 1 & Office cost & Number of visits & 21.875 .800 & 59.993 .990 \\
\hline 2 & $\begin{array}{l}\text { Service Subscription Fees } \\
\text { (Telephone, Electricity and } \\
\text { Water) }\end{array}$ & $\begin{array}{c}\text { Number of visits, Kwh } \\
\text { and } \\
\mathrm{M}^{3}\end{array}$ & 89.348 .731 & 6.822 .490 \\
\hline 3 & Marketing cost & Work hours & 1.000 .000 & 2.873 .205 \\
\hline 4 & Cleaning Service Cost & Floor area & 22.948 .463 & 3.584 .224 \\
\hline \multicolumn{3}{|c|}{ Sub Total } & 35.172 .994 & 3.273 .908 \\
\hline \multicolumn{3}{|c|}{ Total } & 290.405 .257 & 299.147 .243 \\
\hline \multicolumn{3}{|c|}{ Total Overhead Cost } & \multicolumn{2}{|c|}{589.552 .500} \\
\hline \multicolumn{3}{|c|}{ Overhead Cost per action } & \multicolumn{2}{|r|}{244.020} \\
\hline
\end{tabular}

Total HD overhead costs were Rp. 589,522,500.00 and per action of this obtained overhead costs of Rp. 244,020.00. The next step is to charge HD overhead to each activity center. This charging is carried out by making proportional overhead over time for each activity center. This calculation can be seen in the table below. 
Rosmila, G. B., Yaya, R., \& Probadi, F. (2020) The Comparison Of The Unit Cost Of Hemodialysis With Ina Cbg Rates In Muhammadiyah Siti Aminah Hospital. Archives of Business Research, 8(5). 80-95.

Table 9. Charging of Overhead Cost toward Activity Center

\begin{tabular}{|c|l|c|c|}
\hline No. & \multicolumn{1}{|c|}{ Type f activities } & $\begin{array}{c}\text { TIME } \\
\text { (Menit) }\end{array}$ & Charging of overhead cost \\
\hline 1 & Patient Registration & 3 & 2.309 \\
\hline 2 & Weighing & 1 & 770 \\
\hline 3 & Anamneses dan TTV Examination & 5 & 3.849 \\
\hline 4 & Machine Preparation & 5 & 3.849 \\
\hline 5 & Installing Blood Line, Dialyzer, Nacl & 3 & 2.309 \\
\hline 6 & Soaking & 2 & 1.540 \\
\hline 7 & Priming & 10 & 7.698 \\
\hline 8 & Vascular Access Function & 5 & 3.849 \\
\hline 9 & Linking Venus Fistula Artery with Blood Line & 2 & 1.540 \\
\hline 10 & Setting the machine according to dosage & 1 & 770 \\
\hline 11 & Observation & 240 & 184.747 \\
\hline 12 & Doctor Visiting & 6 & 4.619 \\
\hline 13 & Hemodialysis Finalization & 5 & 3.849 \\
\hline 14 & Final Weighing & 1 & 770 \\
\hline 15 & Changing linen & 1 & 770 \\
\hline 16 & Rinsing & 10 & 7.698 \\
\hline 17 & Preparing Patients Status & 15 & 1.540 \\
\hline 18 & Reuse & $\mathbf{3 1 7}$ & 11.547 \\
\hline & & & $\mathbf{2 4 4 . 0 2 0}$ \\
\hline
\end{tabular}

\section{Calculation of Unit Cost HG based on the Modified Baker's ABC Method}

After conducting direct cost calculation, HD direct overhead as well as HD indirect resource overhead then it can be found total cost of HD action in RSUMSA in 2018.

Table 10. Unit cost of HD Action in RSUMSA in 2018

\begin{tabular}{|c|c|c|c|c|}
\hline Type of costs & Total cost & $\begin{array}{c}\text { Number of HD } \\
\text { actions }\end{array}$ & $\begin{array}{c}\text { Unit cost of } \\
\text { HD actions }\end{array}$ & $\mathbf{\%}$ \\
\hline Direct Cost & 1.161 .384 .089 & 2416 & 480.705 & $66,3 \%$ \\
\hline $\begin{array}{c}\text { Direct Resource } \\
\text { Overhead }\end{array}$ & 290.405 .257 & 2416 & 120.201 & $16,6 \%$ \\
\hline $\begin{array}{c}\text { Indirect Resource } \\
\text { Overhead }\end{array}$ & 299.147 .243 & 2416 & 123.819 & $17,1 \%$ \\
\hline Total & $\mathbf{1 . 7 5 0 . 9 3 6 . 5 8 8}$ & $\mathbf{2 4 1 6}$ & $\mathbf{7 2 4 . 7 2 5}$ & $\mathbf{1 0 0 \%}$ \\
\hline
\end{tabular}

Based on the table above it can be seen that the total cost of HD actions in RSUMSA in 2018 was Rp. $1,750,936,588.00$ The number of HD actions in 2018 was 2416 actions, so that the unit cost of HD actions was Rp. 724,725.00.

\section{DISCUSSION}

Hemodialysis Installation in Muhammadiyah Siti Aminah Hosptal (RSUMSA) began operating in March 2018. The method was re-used of 5-7 times. This re-used was conducted by using a re-used 
engine provided by the vendor. At the beginning of operations, the machines used were 4 active machines and 1 backup engine. Until the end of 2018 there have been 5 active machines and 1 backup engine. The machine is held by joint venture (joint operation) method. In Join venture method, the machine is provided by the investor and the hospital is only obliged to shop for consumables and dialysate liquid from the investor. During 2018, there were 2416 HD actions performed by the RSUMSA Hemodialysis Installation.

The hemodialysis dose received by HD patients in RSUMSA is twice a week with the duration of each HD is 5 hours. So that with only 6 machines, RSUMSA can only accommodate 36 patients and carry out 2416 actions. The dosage applied by RSUMSA is in accordance with the recommendations of Pernefri and in accordance with the National Guidelines for the Management of the Final Stage of Kidney Disease Medicine Services determined by the Minister of Health in 2017(11,12). Dose twice a week accordance with the desired Kt / V target of 1.8 which is equivalent to a URR of $80 \%$ $(11,12)$. Meanwhile, according to the 2015 KDOQI Clinical Practice Guidelines for Hemodialysis Update, the recommended minimum HD dose is 3 times a week with a Kt / V target of 1.4 (13). In the latest guidelines issued by The Renal Association in 2019, the hemodialysis dose is 3 times a week with a target Kt / V of 1.2 with a duration of 12 hours a week (14).

Costs for hemodialysis are very dependent on direct costs, especially medical consumables. The use of these consumable medical materials depends on the method used by the hemodialysis machine, which is whether to use the single-used or re-used method. At RSUMSA use the re-use method, so that the cost of purchasing a dialyzer can be reduced. Dialyzer each patient can be reused up to 7x. The cost of BMHP at RSUMSA if using a dialyzer (Complete Package) is Rp. $468,468.00$ whereas if it has been re-used using a package without a dialyzer (incomplete package) that is Rp. $269,178.00$.

Dialyzer re-used up to 7 times at RSUMSA makes the direct cost of HD actions smaller compared to other studies using the 5 times re-used method. In a study conducted by Syafiq Bahaswan at RSI Klaten in 2015, the direct cost of the re-used method reached Rp. 654,424.00 (15). At the RSUMSA the direct cost was found to be Rp. 480,705.00. The re-used method is still permissible as long as the tube dialyzer meets the following conditions: 1) must have a blood compartment volume (or Total Cell Volume / TCV) of at least $80 \%$ of the initial value or urea (or ionic) clearance of at least $90 \%$ of the initial value and 2) it is not recommended to use a low biocompatible membrane dialyzer and made from cellulose $(12,16)$.

Direct costs are also affected by routine investigations done on HD patients. Pernefri and the Minister of Health have recommended 20 laboratory parameters that must be done routinely in HD patients $(11,12)$ In RSUMSA, only 6 laboratory parameters were examined, namely HB, Ureum, Creatinine, HBsAg, Anti HCV and Anti HIV. 6 These parameters are determined by hospital management but not yet with the approval of a Consultant Kidney Hypertension. Determination of these 6 parameters is done to reduce the cost of supporting examinations in HD patients, because other types of parameters cannot be checked independently at the RSUMSA Laboratory Installation. So if all parameters are checked, the costs incurred by the hospital are very large, reaching Rp. 4,020,101.00 because it has to be sent to a third-party Laboratory. 
Rosmila, G. B., Yaya, R., \& Probadi, F. (2020) The Comparison Of The Unit Cost Of Hemodialysis With Ina Cbg Rates In Muhammadiyah Siti Aminah Hospital. Archives of Business Research, 8(5). 80-95.

Tabel 11. Comparison of HD Patient Laboratory Routine Examination between what is done by RSUMSA and Pernefri Recommendation

\begin{tabular}{|c|c|}
\hline $\begin{array}{c}\text { Routine Laboratory Examinations in } \\
\text { HD Patients at RSUMSA }\end{array}$ & Pernefri Recommended Laboratory \\
\hline Haemoglobin & Haemoglobin \\
\hline Ureum & Platelets \\
\hline Creatinine & Ferritin, Fe serum \\
\hline $\mathrm{HCV}$ & Transferrin saturation \\
\hline HIV & Ureum \\
\hline \multirow[t]{15}{*}{ HbsAg } & Creatinin \\
\hline & $\begin{array}{c}\text { Lipid profile (cholesterol, TG, LDL dan } \\
\text { HDL) }\end{array}$ \\
\hline & Uric acid \\
\hline & Bood glucose \\
\hline & Bicarbonat \\
\hline & Potassium and Sodium \\
\hline & Albumine \\
\hline & $\begin{array}{c}\text { Liver Function } \\
\text { (SGOT/ALT,SGPT/AST) }\end{array}$ \\
\hline & $\mathrm{HbsAg}$ \\
\hline & AntiHCV \\
\hline & Anti HIV \\
\hline & CRP \\
\hline & calsium, phosphate \\
\hline & Parathyroid hormone (PTH) \\
\hline & Beta 2 microglobulin \\
\hline
\end{tabular}

If we look at the laboratory parameters recommended by Pernefri, there are several more parameters that can be done by the RSUMSA Laboratory, including platelets, blood sugar, uric acid, lipid profile, liver function (SGOT / SGPT), albumin, and electrolytes (Sodium, Potassium, Bicarbonate, Calcium, phosphate).

Routine and complete laboratory checks are important so that the patient's condition or comorbid disease can also be monitored and given good management. Several studies have shown that the mortality rate of HD patients is determined by several factors including the presence of important comorbid diseases such as cardiovascular disease, diabetes, infections, old age and complications of Chronic Kidney Disease (metabolic acidosis, hyperkalemia and fluid overload) (17-20). Another condition that can increase mortality is malnutrition, this factor is often forgotten to be evaluated $(18,21)$. Diabetes can be seen from the examination of blood sugar. Malnutrition can be seen from albumine examination. Phosphate examination is also important to do in HD patients because abnormal phosphate values can worsen the patient's health condition (22). Examination of liver function is also important because some studies show a decrease in liver enzymes in HD patients(23). So the examinations above are important to be done routinely on HD patients. With RSUMSA's laboratory capabilities, it is necessary to consider adding laboratory parameters that are routinely performed on HD patients, of course taking into account the unit cost of each examination. It is hoped that there is better quality control and cost control at RSUMSA. 
RSUMSA Hemodialysis Installation $100 \%$ income comes from patients who are guaranteed by BPJS. The hospital is paid by BPJS with the INGS CBGS rate of Rp. 737,700. Based on the results of the study above, where HD unit cost gets Rp. 724,725.00, a positive difference or profit from the HD action claim is obtained, amounting to Rp. 12,975.00.

Based on interviews with the Director of RSUMSA, this benefit is considered to be still small, so it needs some more efforts so that HD Installation can provide even greater profits. Efforts that can be made by hospitals include : increasing the number of HD actions through increasing the number of shifts or HD machines but must also be balanced with the efficiency of human resources, electricity and water usage so as to reduce the overhead of HD action. In addition, it is necessary to develop Clinical Pathway of HD measures so that they can be more efficient in the use of consumable medical materials or drugs that must be given during HD actions. Another effort that can be done by hospitals is to increase the class of hospitals from Type D up to Type C so that hospitals can get higher claims.

Table 12. Comparison of HD Unit Cost with INGS CBGS Rates and Hospital Rates
\begin{tabular}{|c|c|}
\hline INA CBGS Tariff & 737.700 \\
\hline Hospital tariff & 1.000 .000 \\
\hline Unit Cost HD & 724.725 \\
\hline $\begin{array}{c}\text { Difference between INA CBGS tariff dengan Unit } \\
\text { Cost HD (a) }\end{array}$ & 12.975 \\
\hline $\begin{array}{c}\text { Difference between hospital tariff with Unit Cost } \\
\text { HD }(\text { b) }\end{array}$ & 275.275 \\
\hline $\begin{array}{c}\text { Explanation } \\
\text { (a) = INA CBGS tariff - Unit Cost HD } \\
\text { (b) = hospital tariff - Unit Cost HD }\end{array}$ \\
\hline
\end{tabular}

During the study, observations were also made on the activities of medical and non-medical personnel involved in HD actions to assess whether there were activities that were non value added or not in accordance with the Standar Operational Procedure (SOP), causing inefficiencies in hospitals, especially in HD installations. Based on observations, there are no non-value added activities carried out by hospital employees. All activities carried out in accordance with the SOP in force in the hospital and in accordance with Pernefri standards. The use of consumable medical materials has also been tightened by making packages of consumable medical materials according to the needs per action, so that no waste is made by HD nurses. Therefore it can be concluded that everything that is done by hospital employees is in accordance with the standards.

\section{CONCLUSION}

Unit cost analysis of hemodialysisi action at Muhammadiyah Siti Aminah Hospital using the activity based costing (ABC) method is Rp. 724,725.00. When compared with the INA CBG rate of Rp. $737,700.00$, a positive difference of Rp. 12,975.00 is obtained. So it give profit to hospital. RSUMSA has not been able to conduct supporting examinations in accordance with the specified standards because the costs incurred will be very high and will cause losses because they exceed INA CBGS tariffs. Potential non-value added activities are not found during hemodialysis service. 
Rosmila, G. B., Yaya, R., \& Probadi, F. (2020) The Comparison Of The Unit Cost Of Hemodialysis With Ina Cbg Rates In Muhammadiyah Siti Aminah Hospital. Archives of Business Research, 8(5). 80-95.

\section{References}

1. Kementerian Kesehatan Republik Indonesia. Cegah dan Kendalikan Penyakit Ginjal dengan Cerdik dan Patuh. Biro Komunikasi dan Pelayanan Masyarakat, Kementerian Kesehatan RI [Internet]. 2018 Mar 7; Available from: http://www.depkes.go.id/article/print/18030700007/cegah-dan-kendalikan-penyakit-ginjal-dengan-cerdik-danpatuh.html

2. Indonesian Renal Register. 10 th Report Of Indonesian Renal Registry. 2017;40.

3. Perkumpulan Nefrologi Indonesia. 8th Report Of Indonesian Renal Registry. 2015; Available from: https://www.indonesianrenalregistry.org

4. Menteri Kesehatan Republik Indonesia. Peraturan Menteri Kesehatan Republik Indonesia Nomor 52 Tahun 2016 Tentang Standar Tarif Pelayanan Kesehatan Dalam Penyelenggaraan Program Jaminan Kesehatan. Direktur Jenderal Peraturan Perundang-Undangan Kementerian Hukum Dan Hak Asasi Manusia Republik Indonesia; 2016.

5. Menteri Kesehatan Republik Indonesia. Peraturan Menteri Kesehatan Republik Indonesia Nomor 76 Tahun 2016 Tentang Pedoman Indonesian Case Base Groups (INA-CBG) Dalam Pelaksanaan Jaminan Kesehatan Nasional [Internet]. Direktur Jenderal Peraturan Perundang-Undangan Kementerian Hukum Dan Hak Asasi Manusia Republik Indonesia; 2016. Available from: https://www.persi.or.id/images/regulasi/permenkes/pmk762016.pdf

6. Baker JJ. Activity-based Costing and Activity-based Management for Health Care. Jones \& Bartlett Learning; 1998. $404 \mathrm{p}$.

7. Javid M, Hadian M, Ghaderi H, Ghaffari S, Salehi M. Application of the Activity-Based Costing Method for Unit-Cost Calculation in a Hospital. Glob J Health Sci. 2015 May 17;8(1):165-72.

8. Chapko MK, Liu C-F, Perkins M, Li Y-F, Fortney JC, Maciejewski ML. Equivalence of two healthcare costing methods: bottom-up and top-down. Health Econ. 2009 Oct 1;18(10):1188-201.

9. Yarikkaya E, Özekinci S, Sargan A, Durmuş ŞE, Yildiz FR. A Comparative Study of Activity-Based Costing vs. Current Pricing System for Pathology Examinations at Okmeydani Training and Research Hospital, Turkey. Turk Patoloji Derg. 2017;33(1):17-24.

10. Mercier G, Naro G. Costing hospital surgery services: the method matters. PloS One. 2014;9(5):e97290.

11. Menteri Kesehatan Republik Indonesia. Keputusan Menteri Kesehatan Republik Indonesia Nomor HK.01.07/MENKES/642/2017 tentang Pedoman Nasional Pelayanan Kedokteran Tata Laksana Penyakit Ginjal Tahap Akhir. 2017.

12. Perhimpunan Nefrologi Indonesia. Konsensus Hemodialisis. 2013.

13. Daugirdas JT, Depner TA, Inrig J, Mehrotra R, Rocco MV, Suri RS, et al. KDOQI Clinical Practice Guideline for Hemodialysis Adequacy: 2015 Update. Am J Kidney Dis. 2015 Nov;66(5):884-930.

14. Ashby D, Borman N, Burton J, Corbett R, Davenport A, Farrington K, et al. Renal Association Clinical Practice Guideline on Haemodialysis. BMC Nephrol. 2019 Dec;20(1):379.

15. Bahaswan S, Pribadi F. UNIT COST PELAYANAN HEMODIALISIS DENGAN METODE ACTIVITY BASED COSTING DI ERA JAMINAN KESEHATAN NASIONAL. 2017;7.

16. Robert Mactier, Nic Hoenich Ph.D,Cormac Breen. Renal Association - Haemodialysis FINAL DRAFT [Internet]. Available from: https://renal.org/wp-content/uploads/2017/06/haemodialysis-5th-edition-1.pdf

17. Chantrel F, de Cornelissen F, Deloumeaux J, Lange C, Lassalle M, registre REIN. [Survival and mortality in ESRD patients]. Nephrol Ther. 2013 Sep;9 Suppl 1:S127-137.

18. Msaad R, Essadik R, Mohtadi K, Meftah H, Lebrazi H, Taki H, et al. Predictors of mortality in hemodialysis patients. Pan Afr Med J [Internet]. 2019 May 28 [cited 2020 Apr 25];33. Available from:

https://www.ncbi.nlm.nih.gov/pmc/articles/PMC6689835/

19. Pladys A, Bayat S, Couchoud C, Vigneau C, McDonald S. Daily hemodialysis practices in Australia/New Zealand and in France: a comparative cohort study. BMC Nephrol [Internet]. 2019 May 7 [cited 2020 Apr 25];20. Available from: https://www.ncbi.nlm.nih.gov/pmc/articles/PMC6505110/ 
20. Anutrakulchai S, Mairiang P, Pongskul C, Thepsuthammarat K, Chan-On C, Thinkhamrop B. Mortality and treatment costs of hospitalized chronic kidney disease patients between the three major health insurance schemes in Thailand. BMC Health Serv Res. 2016 29;16(1):528.

21. Wang W-L, Liang S, Zhu F-L, Liu J-Q, Chen X-M, Cai G-Y. Association of the malnutrition-inflammation score with anthropometry and body composition measurements in patients with chronic kidney disease. Ann Palliat Med. 2019 Dec 11;8(5):596-603-603.

22. Ray A, Esparza S, Wu D, Hanudel MR, Joung H-A, Gales B, et al. Measurement of serum phosphate levels using a mobile sensor. The Analyst. 2020 Mar 2;145(5):1841-8.

23. Sette LHBC, de Almeida Lopes EP. Liver enzymes serum levels in patients with chronic kidney disease on hemodialysis: a comprehensive review. Clinics. 2014 Apr;69(4):271-8. 